\title{
Authorship, Book History, and the Effects of Artifacts
}

Towards the end of the dedicatory epistle in his De historia stirpium commentarii insignes (Basel, I542), Leonhart Fuchs turned his attention away from the study of plants to commend the person responsible for bringing his massive illustrated botanical text to fruition:

At this point I should say more about the hard work and care in the printing of this book by Michael Isingrin, the most painstaking printer of Basel, except that we know that these qualities are sufficiently known and proved by the many works that have issued from his workshop for some years now. And surely this work speaks for itself well enough, as to how diligent he was in printing it. However, how great an expense he was put to can be estimated by anyone who cares to weigh the magnitude of the work and the pictures themselves for their quality. Students of herbal matters owe much to this man, who spared neither expense nor labor in order to serve their convenience and aid their pursuits.

But the fact is that there are many today who, like drone bees, sneak into other people's labors and by their inept copying spoil and debase books that were set up in the best and most elegant type and adorned with superb pictures. This is done for no other reason than to profit at the expense of others. Since this is so, we must have a thought of Isingrin, too, who has incurred enormous expense in publishing this work; and to that end a prohibition has been issued by imperial decree, that no one else anywhere may print these our commentaries without penalty, as we warned at the very beginning of this book. ${ }^{\mathrm{I}}$

Though his dedicatory epistle appears in the first pages of the printed book, Fuchs seems to suggest that he holds the remainder of the volume in his

\footnotetext{
I Meyer et al., Great Herbal, I:215. The warning that Fuchs refers to appears on the book's title page: "Furthermore, by the decree of CHARLES INVINCIBLE EMPEROR, warning is given that no other person goes without punishment who anywhere in the world prints these commentaries on the history of plants, just as was said in the privilege previously made known to us" (I:49). Meyer et al. point out that the "flowery language" of the title page was likely determined by Isingrin rather than Fuchs (I:50).
} 
hands as he writes - as indeed he very well may have done. De historia stirpium's preliminaries (including a title page, full-length author portrait, dedicatory epistle, explanation of difficult terms, and tables of plant names in Greek, Latin, German, and in the contemporary jargon of apothecaries) were likely printed last, and Fuchs's epistle may have been written while he reviewed the bulk of Isingrin's labor, enabling him to anticipate the experience of future readers encountering his book for the first time. ${ }^{2}$ When readers encounter a physical copy of De historia stirpium, Fuchs's insistence that Isingrin is "the most painstaking printer of Basel" can be readily verified in the very weight and materials of this folio. Held in the hands, Fuchs and Isingrin's volume is appreciably, monumentally, voluminous.

De historia stirpium's magnitude makes it obvious that Isingrin took a considerable risk in supplying the immense capital needed to publish the volume. As the grateful Fuchs explains, Isingrin's industry has been protected by an "imperial decree," and Fuchs's phrasing makes explicit the way that Renaissance legal protections over books primarily concerned not the intellectual property of their authors but the financial interests of their publishers. As a professor at the University of Tübingen, Fuchs received an annual subsidy from his employer to supplement the costs of his publications, and his sympathies for Isingrin's costs are impossible to separate from this shared investment in the publisher's role. ${ }^{3}$ Nonetheless, though Fuchs claims authority over "these our commentaries" as both an author and a publisher, his phrasing makes it clear he understands that the ultimate rationale for the imperial decree is to guard Isingrin's outlay of the capital needed to produce the printed volumes rather than his own investment of scholarly and creative labor in the production of the verbal text and the illustrations it contains.

Much to Fuchs's indignation, however, the imperial decree protecting De historia stirpium was insufficient to keep unauthorized agents from mimicking elements of the book. Nearly immediately after it appeared, De historia's carefully produced illustrations were copied and adapted to accompany a new edition of Dioscorides' De materia medica edited by

\footnotetext{
2 On the practical advantages of printing preliminary material last, see Peter W. M. Blayney, The Texts of King Lear and Their Origins (Cambridge: Cambridge University Press, 1982), 95-96.

3 Fuchs's salary in 1535 was I60 florins, with an additional is florins each for housing and for "publishing his own books" (Meyer et al., Great Herbal, r:283). Assuming a Rhenish florin and an exchange rate of $4 \mathrm{I}$ pence sterling per florin, Fuchs's annual salary as a professor was roughly equivalent to $£_{27}$, and his publishing subvention added another $\mathfrak{2}_{2.5}$. See John H. Munro, "The Coinages of Renaissance Europe, ca. I500,” in Thomas A. Brady (ed.), Handbook of European History, 1400-1600: Late Middle Ages, Renaissance, and Reformation, Vol. I (Leiden: Brill, 1994), 67I-678.
} 
Walther Ryff and published in Frankfurt by the printer and block-cutter Christian Egenolff (I543, USTC 68335I). Egenolffs encroachment on Fuchs's work was neither surprising nor unprovoked: even as Fuchs praised the quality of Isingrin's printing in his 1542 epistle, he also expressly condemned Egenolff s skill as a printer and implied that the universityeducated Egenolff lacked the knowledge needed to publish works of botany. In condemning Egenolffs ignorance, Fuchs elevates his own professional status as a physician by implying that the study of botany is too sophisticated to be understood by lay figures without appropriate scholarly instruction. Later in his epistle, Fuchs notes that he has simplified some of his botanical descriptions specifically to suit the needs of such unprofessional readers: "since in relating the history of plants we had to use terms somewhat abstruse and remote from the knowledge and understanding of the lay reader, we have judged it worthwhile to add some short explanation of these terms so that the less knowledgeable reader would not be handicapped." 4 While it is possible to read Fuchs's readerly concerns as genuine, his condemnation of "drug sellers, a largely ignorant class of men" and "stupid and frightfully superstitious old wives" elsewhere in the epistle suggests that his remark about lay readership is part of a larger performance of self-promotion, making his concerns about the lay reader a form of intellectual noblesse oblige. ${ }^{5}$ When it is seen within this broader intellectual context, Fuchs's attempt to position Egenolff outside of professional and authentic studies in German natural history can be recognized as it was intended: as a deliberate and pointed affront.

Fuchs's insult was also motivated by Egenolffs history of unauthorized herbal publication. A decade earlier, in I533, Egenolff had published the first edition of Eucharius Roesslin's Kreuterbuch and copied the woodcuts of physician Otto Brunfels's Vivae eicones herbarum (Strasbourg, I530I536), which had been published by Johannes Schott under the protection of imperial privilege. Schott sued Egenolff for violation of his privilege, and Egenolff defended himself by claiming that images of the natural world such as plants could not be protected as works of art by virtue of their innate similarities: a daffodil could only ever look like itself, and the ultimate artist responsible for its image is God. ${ }^{6}$ As I explain in Chapter 3, Fuchs had devoted considerable effort in hiring artists to render De historia's botanical illustrations to his precise specifications, and his

\footnotetext{
4 Meyer et al., Great Herbal, I:2I4. 5 Meyer et al., Great Herbal, I:204.

${ }^{6}$ Sachiko Kusukawa offers an account of the dispute between the two men in Picturing the Book of Nature, 87-89, as does Meyer et al., Great Herbal, ı:80I-804.
} 
attack on Egenolff suggests that Fuchs thought the printer's illicit replication of Brunfels's woodcuts would make Fuchs's own botanical scholarship vulnerable to the replication of errors caused by unauthorized reprinting. "Among all the herbals extant today," Fuchs claims, "none are so full of stupid errors as those the printer Egenolff published again and again." ${ }^{\prime 7} \mathrm{He}$ points out that Egenolff s herbals reused woodcuts to illustrate two distinct species of plants, and these errors stemmed as much from the printer's avarice as from Egenolff s botanical ignorance: "he does not regard the rewards of scholarship as of much account and is more intent on making money, it is no wonder that books of this sort come from his workshop." Fuchs's easy dismissal of a publisher's livelihood as merely "intent on making money" finds an analogue in some modern accounts of herbals, where historians find it inexplicable that sixteenth-century craftsmen were "out to make quick money" rather than to produce their wares primarily for the benefit of authorities attempting to lay claims to a new discipline. ${ }^{9}$

Fuchs's preface makes it clear that he separates publishers into two distinct categories. There are those publishers who, like Isingrin, put their livelihoods into the service of herbal authors like himself, and there are nefarious privateers like Egenolff who resist such authorial deference and seek to publish herbals for their own financial gain. In setting himself up as Isingrin's champion, however, Fuchs once again bolsters his own intellectual and authoritative pretentions. He conveniently elides his reliance on a publisher for the propagation of his authoritative herbal knowledge, masking the way that his authorship depends entirely on the dissemination of printed books. While unillustrated and anonymous botanical works like Agnus castus might have flourished in manuscript, Fuchs's De historia stirpium relied entirely on the precise correspondence of image and text that could be maintained only through a medium as relatively stable - and as technically difficult to produce - as print. It is through such rhetorical sleight of hand that Fuchs attempts to prevent his readers from understanding that, without the likes of Isingrin or Egenolff, there would be no illustrated printed herbals for sale at all. ${ }^{\text {IO }}$

Egenolffs issuance of Dioscorides' text alongside copies of the De historia woodcuts thus did not just violate privilege; it threatened the

\footnotetext{
7 Meyer et al., Great Herbal, i:2ıo. $\quad{ }^{8}$ Meyer et al., Great Herbal, i:2Io.

9 Morton, History of Botanical Science, I23.

10 Similar sentiments also appear in England. J. W. Binns's work on the printing of Latin texts suggests that by the I57OS such accounts of the "mercenary unimaginativeness of English printers" were commonplace. See Intellectual Culture in Elizabethan and Jacobean England: The Latin Writings of the Age (Leeds: Francis Cairns Press, 1990), 402-403.
} 
terms of Fuchs's status as an expert, and Fuchs publicly condemned Egenolff's thievery in a work that was both published and printed by Isingrin. In Apologia ... qua refellit malitiosas Gualtheri Ryffi veteratoris pessimi reprehensiones (Apologia, by which he refutes the malicious criticism of the sly fox, Walther Ryff, Basel, I544, USTC 602518), Fuchs cites both the financial loss to Isingrin and the damage by copying done to the reputation of the cutter of the De historia's original woodblocks, Veit Rudolf Speckle. Having had this fight over botanical images before, Egenolff was well equipped to answer Fuchs's charges, and he quickly countered with his own pamphlet: Adversum illiberales Leonhardi Fuchsij, medici Tubingensis ... calumnias, responsio (A refutation of the unjust, false accusations of Leonhart Fuchs, doctor of Tübingen; Frankfurt, 1544, USTC 609318). In Responsio, Egenolff repeated his earlier defenses and even extended his argument to attack the originality of Fuchs's botanical commentary. In defending his use of Fuchs's woodcuts, Egenolff claimed that, because much of the text of De historia had been lifted not from Fuchs's own experience but from the works of other botanists, it was hypocrisy for Fuchs to identify himself as the text's author with a full-length title portrait. By clothing himself in the scholarship of his botanical betters, Egenolff argued, Fuchs's expert status was vulnerable, as once these scholars come to reclaim their authority, "very soon we shall see him completely skinned, this mangy, quite hairless little fox." ${ }^{\text {II }}$ Not only, Egenolff claimed, were Fuchs's images of plants mere copies of the book of nature but Fuchs's own expertise was merely the stuff of so many other books. The implicit fraud that Egenolff leveled against Fuchs's skill as a botanist is an insult that would later resonate with herbalists like Turner and Gerard, who used their paratexts to try to foreclose the possibility that readers might level the same accusation at them.

Egenolff s acerbic quarto prompted Fuchs to respond in kind: Adversus mendaces et Christiano homine indignas Christiani Egenolphi typographi Francofortani suique architecti calumnias responsio (A reply to the mendacious calumnies, unworthy of a Christian, of Christian Egenolff, the Frankfurt publisher, and his architect; March 1545). Fuchs had intended for his second tract against Egenolff to circulate through the continental republic of letters via the 1545 Frankfurt Book Fair, but agents working for Egenolff managed to purchase all of the copies that its Basel publisher, Ulric Morhart, offered for sale and then presumably destroyed the pamphlets. None is now extant. In a print battle between an author and

${ }^{\text {II }}$ Quoted and trans. in Meyer et al., Great Herbal, r:846n9. 
a publisher, the publisher clearly has an advantage. Defeated, Fuchs was forced to seek out another publisher for the work's second edition (Basel: Erasmus Zimmermann August 1545; USTC 602515), where he offered his account of what had happened to the first. ${ }^{\mathrm{I2}}$

Fuchs had many such disputes in print over the course of his long career as a herbalist and as a physician, and they were eagerly followed by contemporaries throughout Europe. His dispute with Egenolff, Fuchs suspected, was really with Janus Cornarius (I500-I558), a humanist physician who felt not only that Fuchs's writings on Greek medicine had effectively plagiarized his own but also that Fuchs was dishonest in allowing successive editions of his own books to be printed under different titles, presumably to confuse potential buyers who had already purchased a previous edition. Thus, in condemning not only Egenolff but also "his architect" throughout this second tract, Fuchs responded to the accusation that he plagiarized the work of his predecessors by once again calling the publisher's intellect into question and by condemning Egenolffs mendacity. Egenolffs criticisms must have been spurred at the behest of some other agent, Fuchs maintained, someone with a greater intellectual investment in botanical authority, rather than a mere publisher who is interested only in the commercial bottom line. Regardless of that bottom line, however, the artisanal fraternity that bookselling engendered in its practitioners enabled Egenolff to snuff out all evidence of Fuchs's authorship of a particular pamphlet. Fuchs's status as a botanical authority was assured for the remainder of his lifetime, but to his continued dismay, publishers held a great deal of power over those who wished to benefit from the broadcast potential of print. To succeed in print, therefore, even widely esteemed herbalists needed to know their place.

To examine how Renaissance authorship was a mode of self-fashioning, this chapter highlights that authors' claiming of an expert knowledge domain depends upon readers' willingness to recognize that authority. I suggest that to better understand the circumstances in which Renaissance herbals were commissioned, authored, and sold within a trade of ideas, scholars need to make a "bibliographic turn," to see herbals not just as verbal texts but also as printed commodities. I argue that by conceiving of a "stationer-function," a discourse of textual authority that is able to operate even in the absence of an author, we have a better way of accounting for the popularity of both named and anonymous books with

I2 On Fuchs's dispute with Egenolff, see Meyer et al., Great Herbal, r:8oI-804 and Kusukawa, Picturing the Book of Nature, I25-I26. 
Renaissance readers. Further, by attending to the circumstances in which printing took place, scholars attuned to a stationer-function can provide a more complete picture of the conditions in which natural history and medical knowledge circulated in sixteenth- and seventeenth-century England. Instead of valorizing authors as if they alone were responsible for making their works publicly available to readers, this approach can help us recognize that botanical works like herbals circulated because of the concerted efforts of booksellers and printers.

\section{Self-Fashioning and the Sociology of Truth}

The above-discussed account of Fuchs's De historia stirpium demonstrates how Renaissance publishers were attentive to, and sometimes directly implicated in, disputes about the authorship of herbal texts. It is also evidence of the way that clashes over the accurate representation of details of natural history and medicine could rapidly descend into accusations of piracy (the unauthorized reproduction of material documents owned by another publisher) and the related but separate offense of plagiarism (the unauthorized reproduction of verbal works written by another author). When scholars account for these conflicts, however, they can sometimes conflate these two activities in ways that confuse the distinct concerns of the affected parties and mistake the text of verbal work for the material document that contains it. ${ }^{13}$ So too, it seems, did early modern authors, though when they conflated plagiarism and piracy they did so for deliberate and self-aggrandizing purposes. As they dedicated their works to esteemed would-be patrons, ambitious authors of herbals like Fuchs had a vested interest in downplaying their dependence upon the financial means of publishers and the technical skill of printers, and it served their attempts at self-fashioning to use their paratexts to depict these agents simply as arms-length financial backers or unlearned mechanicals rather than as powerful figures and artisans responsible for instigating the creation of an author's books. Fuchs's complimenting of Isingrin's "diligence" and "elegant type" thus betrays his anxieties over this dependency just as much as his condemnation of the "inept copying" of "drone bees" like Egenolff. As Fuchs insists that only the integrity of the individual agent involved separates a good printer-publisher from a bad one, he reveals his uneasy

\footnotetext{
I3 Sometimes both offences can - and did - occur simultaneously. The crucial point, however, is that plagiarism is a crime against authors and piracy is a crime against the legal owner of a text. In the Renaissance, the owner of a text was most often its publisher, not its author.
} 
awareness that his botanical labors can be broadly recognized as "authorial" only through the publication efforts of another party, one with their own vested interest in the production of printed herbals. As Adrian Johns has succinctly remarked, "[t]here could be no substitute for publication if one wished to establish knowledge, and ways of securing knowledge, in a wider world." ${ }^{4}$

The denigration of other agents' motivations, particularly others' economic motivations, is a crucial part of establishing the veracity of "scientific" truth claims. Steven Shapin's research has demonstrated that, despite seventeenth-century scientists' attempts to characterize factual knowledge about the world as grounded in their own direct experience, what scientists put forward as "truth" was in fact socially constructed via the testimony, and the authority, of other scientists and invested onlookers. Readers' knowledge of early modern natural history was thus based in scientists' relationships with those figures who were trusted to accurately represent and verify their accounts of their world. "Wh "What we call 'social knowledge' and 'natural knowledge' are hybrid entities," Shapin writes. "[W] hat we know of comets, icebergs, and neutrinos irreducibly contains what we know of those people who speak for and about these things, just as what we know about the virtues of people is informed by their speech about things that exist in the world." 6 Shapin asserts that the paradigm of seventeenth-century veracity was the English gentleman, a figure like Robert Boyle whose breeding, discretion, and financial acumen enabled him to be sufficiently indifferent to possible outcomes and therefore unbiased in his accounting of reality: "[a] selfless self was a free actor in a world of knowledge; all others counted as constrained." 77 In Fuchs's articulation of his authority over herbal knowledge, he follows a similar strategy by celebrating the efforts of a publisher such as Isingrin, who, like Fuchs himself (and unlike the seemingly acquisitive Egenolff), is motivated not by money but by civil and scientific truth. Fuchs notes that Isingrin's labor and expense were designed not for profit but to serve the higher purpose of attending to the needs of scholars of botany, "in order to serve

\footnotetext{
${ }^{14}$ Adrian Johns, The Nature of the Book: Print and Knowledge in the Making (Chicago: University of Chicago Press, 1998), 489. On natural historians' anxieties about print publication in seventeenthcentury England, particularly those of John Aubrey, see Elizabeth Yale, Sociable Knowledge: Natural History and the Nation in Early Modern Britain (Philadelphia: University of Pennsylvania Press, 2016), I28-I29. On the naturalist community of letters more broadly, see Ogilvie, Science of Describing, esp. 74-86.

is Steven Shapin, A Social History of Truth: Civility and Science in Seventeenth-Century England (Chicago: University of Chicago Press, 1994).

${ }^{16}$ Shapin, Social History of Truth, xxvi. ${ }_{17}$ Shapin, Social History of Truth, 182.
} 
their convenience and aid their pursuits." ${ }^{\text {I8 }}$ So, even as Fuchs speaks of the value that Isingrin brings to Fuchs's own botanical project, he makes the publisher's material and economic needs secondary to Fuchs's own intellectual ambitions. Thus, while the quality of the material form of the book is being celebrated, the product of the printer is demoted, and the importance of the verbal text created by the author is made superior to the material text produced by the printer.

The authority that Fuchs claims for himself derives from his creation of a verbal and illustrative work that represents a host of knowledge about plants, but his feuds with Egenolff and others make it clear that he realizes his authority does not fully extend to the representation of that work in book form. In other words, the way that readers received Fuchs's knowledge was mediated by the efforts of other figures who had the power to reinforce or to undermine Fuchs's expertise. Fuchs understood that his authority was dependent upon stationers, and he resented it. While authorial fears about loss of control are perennial, the technology of print led to an intensification of these concerns. ${ }^{19}$ This observation suggests that Shapin's claims need to be modified to account for the material means by which knowledge was transmitted. In the case of authority derived from individual reading acts, historians of ideas need to account for the reality and the sociology - of printed books.

In my Introduction, I argued that scholars of early English printed herbals have focused their efforts so intently on the content of botanical works that they have often overlooked the material means by which these works were disseminated. As upcoming chapters will show, the popularity with lay readers of small anonymous works like the little Herball spurred London publishers to invest in newer, larger, and more comprehensive botanical works, many of which they specifically commissioned from authors, artists, and translators. Authorized English herbals were thus not fully autonomous textual creations that affirmed the reality of plants with varying degrees of accuracy but speculative books that publishers sometimes asked authors to produce in order to appeal to particular clienteles. In turning herbal scholarship towards an appreciation of the work of printers and booksellers, I want to suggest that these other agents need to be considered authoritative in the process of making botanical works available to early modern readers. The histories of these other agents have largely

${ }^{18}$ Meyer et al., Great Herbal, i:215.

I9 See Elizabeth Eisenstein, Divine Art, Infernal Machine: The Reception of Printing in the West from First Impressions to the Sense of an Ending (Philadelphia: University of Pennsylvania Press, 20II), esp. $2 \mathrm{I}-22$. 
been hidden from view as authors' social and intellectual pretentions required them to downplay the important role of those who literally constructed the material means through which their botanical works reached audiences.

\section{"Print Culture," "Piracy," and "Plagiarism"}

In this extension of authority to include the artisans who financed and manufactured the verbal works of authors, I am engaging with arguments similar to those made by Adrian Johns in The Nature of the Book: Print and Knowledge in the Making. By drawing what he calls "the first real attempt to portray print culture in the making," Johns explains the means by which printed books "became trustworthy." Johns refers to "print culture" in his 1998 monograph, a phrase that has declined in use in recent years. He acknowledges that the phrase was popularized by Marshall McLuhan in his 1962 book The Gutenberg Galaxy: The Making of Typographic Man, but Johns draws his concept of "print culture" directly from Elizabeth Eisenstein, who situates the term as a catchall phrase designed "to refer to post-Gutenberg developments in the West when setting aside its possible relevance to pre-Gutenberg developments in Asia." "2r As the subtitle of her own volume suggests, Eisenstein's goal in her monumental The Printing Press As an Agent of Change is to explore the role that the products resulting from Gutenberg's new technology played in "cultural transformations in early-modern Europe." Google Books Ngram Viewer, which displays a graph showing how a word or phrase has occurred in a corpus of digitized English books over a selection of years, records increased frequency in the phrase "print culture" from the early 1960s, corresponding with McLuhan's work, while a steep spike in the use of the phrase can be seen from 1980 onwards, corresponding with the reception of Eisenstein's book. As debates have raged over the agency and ontology of inanimate print, "print culture" has been in sharp decline since 2006, possibly as a result of its replacement by the related phrase "book history," which has been in increasing use. (In 2013, Peter W. M. Blayney surveyed the discipline in his history of the Stationers' Company of London and dryly remarked, "[t]he only sentence in this book in which the words print and culture both appear is this one." $)^{22}$ Johns repeatedly insists that Eisenstein

${ }^{20}$ Johns, Nature of the Book, I9, 3.

${ }^{21}$ Johns, Nature of the Book, 2nI; Eisenstein, Printing Press As an Agent of Change, xiv.

22 Blayney, Printers of London, xvii. 
characterizes print culture chiefly through print's capacity to endow "fixity" upon knowledge domains; however, her two-volume work of historical synthesis also explores myriad other features of cultural change that she sees resulting from the mass production of textual products, including dissemination, reorganization, data collection, preservation, amplification, and reinforcement, all of which, I argue, have particular relevance to the development of English botanical science throughout the sixteenth century.

In Nature of the Book, Johns recasts Eisenstein's arguments about "fixity" to note that it is a "transitive" quality of printed texts that is "recognized and acted upon by people." Johns's new formulation of fixity is instructive for the arguments of the present volume, as Johns's approach to print culture turns towards both the agents responsible for producing books and the varied readers who used them. Johns's understanding of what he calls print's "credit" builds directly on Shapin's concept of trust but moves the focus from trusted individuals to the ways trusted individuals can be understood through printed artifacts. He maintains that a Renaissance reader first approached a printed book cautiously and sought to make "a critical appraisal of its identity and credit" chiefly by assessing "the people involved in the making, distribution, and reception of books." ${ }^{23}$ While earlier historians had viewed early modern readers as unthinkingly credulous, Johns finds readers to be highly apprehensive and even suspicious, attuned to the ubiquitous possibility that the texts of printed books may be something other than what they seem. To Johns, "[p]iracy and plagiarism occupied readers' minds just as prominently as fixity and enlightenment. Unauthorized translations, epitomes, imitations, and other varieties of 'impropriety' were, they believed, routine hazards." ${ }^{24}$ To reassure themselves of the authority of a particular publication, Johns asserts, readers would first have to evaluate the credibility of printers and booksellers who produced and marketed it for sale, using the artifact as a surrogate for the agents who manufactured it. "The ways in which such agents thought of and represented themselves," he writes, "were therefore of central importance to the received credit of printed knowledge." ${ }^{25}$ Through what Johns calls the "character" of printers and booksellers, an author's credibility over a knowledge domain might then safely be established.

Johns expands upon this point by exploring the particular means in which England's Royal Society in the later seventeenth century came to be

${ }^{23}$ Johns, Nature of the Book, 3I-32. ${ }^{24}$ Johns, Nature of the Book, 30.

25 Johns, Nature of the Book, 34 . 
viewed as an authoritative locus for natural philosophy by highlighting the ways that its members harnessed all elements of the medium of print, from maintaining its own printing houses and periodical journal, Philosophical Transactions ( $1665-)$, to overseeing a series of public-facing correspondences between its membership. Johns demonstrates that the scientific authority claimed by the Royal Society was due in no small part to the social status accorded its members, whose status as witnesses to the experiments it conducted "would be apportioned credit according to their place in the social hierarchy, and in particular according to their received status as gentry." ${ }^{26}$ Johns asserts that the establishment of epistemological credit in printed works of natural philosophy was the result of a concerted effort among not only authors and authorized witnesses to experiments but also book producers and sellers - namely stationers. Yet as book producers, stationers mediated the relationship between authors and readers, and their reputation could influence the reception of a particular book:

In managing publications, Stationers, and often booksellers in particular, controlled events. The practices and representations of their domains affected every character and every leaf of their products. Isolating a consistent, identifiable, and immutable element attributable to the individual author would be virtually impossible in these circumstances. Attributing authorship was thus intensely problematic for both contemporary and future readers. A priori, virtually any element in a work might or might not be the Stationers' responsibility, in virtually any field of writing ... [t] he reading of a book could in consequence be substantially affected by the perceived conduct, and above all the perceived character, of the Stationer or Stationers who had produced it. ${ }^{27}$

Johns's evidence is derived primarily from the later Stuart period, which influences how he reads earlier events that adhered to different customs and systems of textual ownership. ${ }^{28}$ As he is particularly invested in the machinations and social pretentions of figures associated with the dissemination in print of works of natural history created by gentry and members of the Royal Society, it is unsurprising that Johns's research primarily concerns evidence not only from the later seventeenth century but that foregrounds the identity of texts' purported authors - as well as the identity of the stationers who supported or undermined these scientific endeavors. This focus, however, has the consequence of misrepresenting the nature of bookselling in the first century of English printing and leaves Johns

26 Johns, Nature of the Book, 470. ${ }^{27}$ Johns, Nature of the Book, I37-I38.

${ }^{28}$ Peter W. M. Blayney shares my concerns; see Printers of London, I8InB. 
without the ability to explain how the book trade operated before the Stationers' Company of London gained a monopoly over printing in I557 or how anonymous popular texts like the little Herball and The Grete Herball found eager purchase at the hands of thousands of early modern readers. This deficit becomes particularly acute in Johns's articulation of piracy, or illicit printing, which he claims to be inextricably bound up in accusations of textual transgression from the period.

Johns uses the term "piracy" to denote:

the unauthorized reprinting of a title recognized to belong to someone else by the formal conventions of the printing and bookselling community. But it soon came to stand for a wide range of perceived transgressions of civility emanating from print's practitioners. As such, almost any book could, in principle, find itself accounted a piracy, whatever its actual circumstances of production and distribution. ${ }^{29}$

In his opening "Note on Conventions," Johns acknowledges the anachronism concomitant with his extended definition of the term, which scholars such as John Feather, among others, caution should be limited to serving its contemporary legal sense of "printing without his or her permission of a text that was clearly and legally owned by another agent." ${ }^{30}$ Johns, however, demurs:

while such precision is probably necessary in matters of technical bibliography, the stipulation seems rather too restrictive for a work such as this, which deals with social, cultural, and intellectual history. Such a book is entitled to recover the broader meanings recognized by contemporaries indeed, it is its duty to do so. Contemporary usage provides warrant. Someone might call an unauthorized printing of personal letters a piracy, for example, even though their ownership had not been registered beforehand; similarly, an unauthorized reprint produced in another country for sale on the Continent might be accounted a piracy, although it was outside English legal jurisdiction. There are no legal terms for such cases, although individuals certainly felt them to be transgressions of some sort. It would be awkward to have to resort every time to "unauthorized reprint" or some such formula. For the sake of conciseness and dramatic value, then - and not least to capture something of the sheer sense of outrage displayed by the aggrieved - I have chosen to follow what I take to be the emerging usage of the time, and call these activities by the generic label of piracy. ${ }^{31}$

29 Johns, Nature of the Book, 32.

30 Johns, Nature of the Book, xx; John Feather, "English Book Trade and the Law," Publishing History I2 (I982): 5I-76.

${ }^{31}$ Johns, Nature of the Book, xx. 
Johns labors throughout The Nature of the Book to provide "the first extensive taxonomy of practices labeled piratical - from piracy itself, through abridgment, epitomizing, and translation, to plagiarism and libel ... In short, it addresses precisely the epistemic significance of piracy." ${ }^{32}$ As Eisenstein later noted, Johns's definition unhelpfully serves to "stretch[] the term 'piracy' to cover nearly every kind of printed output that was not specifically authorized." ${ }^{33}$ While there may be cause to expand textual impropriety in this way in very specific contexts, such as the reception of works by members of the Royal Society, it is all but useless in understanding the publication of books in the sixteenth century. A book such as John Skot's reprint of Bankes's edition of the little Herball (STC 13175.4), being anonymously authored as well as printed prior to the incorporation of the Stationers' Company in 1557 (thus lacking both author and Company authority), would be implicated by Johns's concept of piracy, irrespective of any logical applicability to this particular publication or to its other pre-I557 reprints. ${ }^{34}$

Another concern with Johns's use of the term "piracy" lies in the way that his preference for "dramatic value" allows him not only to ignore the scholarly "precision" presumably favored only by "technical bibliographers" but also to misrepresent the agents who were responsible for coining and popularizing the term, in order to accord with his book's thesis that the strictures of fixity and veracity associated with printed books of natural philosophy were constructs hard-won by books' various producers. Early in his first chapter, Johns claims (without a source) that "the term [piracy] seems to have been coined by John Fell, Bishop of Oxford, to describe the rapacious practices of London printers and booksellers"; nearly 300 pages later, a footnote reveals that "It was in the early i670s, as part of the closely related struggle between Oxford University and the Stationers' Company, that Bishop John Fell seems to have coined the term 'pirates' to refer to printers and booksellers who invaded others' literary propriety: see below"; thirty-one pages later, persistent readers eventually learn that "when John Fell, bishop of Oxford and the leading proponent of Oxford printing,

32 Johns, Nature of the Book, 33.

33 Elizabeth Eisenstein, “An Unacknowledged Revolution Revisited," American Historical Review I07 (2002): 87-105; 96.

34 Johns modifies this position slightly in Piracy: The Intellectual Property Wars from Gutenberg to Gates (Chicago: University of Chicago Press, 2009), where he asserts that "piracy was an invention of the seventeenth century" (I9). His account of the regulatory function of the Stationers' Company of London in this book, however, is extremely short (24-27) and does not cite any of the numerous and detailed studies of the Company or the Stationers' Registers by bibliographers and historians of the book. 
wanted to describe to Sir Joseph Williamson his frustration at the invulnerable community of London Stationers who violated the university's 'propertie in Printing,' Fell called them 'land-pirats.' It was an evocative phrase, and one that would last." ${ }^{\text {'5 }}$

Johns's footnote on "land-pirats" cites a manuscript letter dated August 6, I674, held in the Public Record Office, and Johns notes that " $[\mathrm{t}]$ his is the earliest reference given in the OED; similar phrases occur in several writers of the time, however, and those who concern themselves about such things may question Fell's absolute priority." ${ }^{36}$ As of the $O E D$ 's updated third edition of June 2006 , the first recorded usage of "pirate" to denote "[a] person or company who reproduces or uses the work of another (as a book, recording, computer program, etc.) without authority and esp. in contravention of patent or copyright; a plagiarist. Also: a thing reproduced or used in this way" (n.3.a) was Thomas Dekker in his exhortation to "[b]anish these Word-pirates (you sacred mistresses of learning) into the gulfe of Barbarisme," found on sig. A4r of his 1603 plague pamphlet The Wonderful Yeare. The earlier OED entry for "pirate" and the one cited by Johns in his 1998 text derives from the second edition of the $O E D$ published in 1989, which then offered as its first entry an exemplar reading "[s]ome dishonest Booksellers, called Land-Pirats, who make it their practise to steal Impressions of other mens Copies." This entry, however, is not ascribed to John Fell, Bishop of Oxford in "the early I670s," but rather is credited to the authorship of the London bookseller John Hancock in 1668. As an "invulnerable" London stationer, Hancock was presumably the sort of "land-pirat" that so incensed Bishop Fell that Fell was moved to write the English Secretary of State Joseph Williamson to request the issuance of some kind of appropriate sanction. Johns's appreciation of the "dramatic value" of the term "piracy" has limited the usefulness of his analysis, causing him to mistake the concerns of the agent who coined an evocative phrase. As a London stationer, Hancock was frustrated with "pirates" not merely out of a concern for propriety but because such behaviors put his (and others') livelihoods at risk by undermining their exclusive rights to sell particular titles they'd registered with the Stationers' Company. By ascribing Hancock's words to Bishop Fell, Johns has confused the stakes of the dispute by turning a coinage derived from an internal commercial matter into one of civic decorum.

${ }^{35}$ Johns, Nature of the Book, 33, 313ni26, 344.

36 SP 29/36I, nos. I88-I88(i). The PRO merged with the Historical Manuscripts Commission to become The National Archives in 2003. 
Considering the earlier usage of 1603 now credited in the updated $O E D$ only adds to the problem. Thomas Dekker's use of "Word-pirates" needs to be appreciated in light of Dekker's career as a prolific and opportunistic playwright and pamphleteer whose vested interests in self-promotion were so well known to his contemporaries that he was lampooned in Ben Jonson's Poetaster and Cynthia's Revels. Dekker is mentioned dozens of times in Philip Henslowe's diary between 1598 and I602, often for revising or "script-doctoring" other authors' plays - collaborative activities that have complicated scholarly attempts at authorship attribution. ${ }^{37}$ Dekker's repeated imprisonment for debt and his continued dependence on his pen for his livelihood require careful contextualization to unpack the motivations behind his portmanteau coinage of a term like "Word-pirates." ${ }^{38}$

Too easily accepting at face value the many accusations of textual impropriety that pervade texts of natural history throughout the sixteenth and seventeenth centuries would mean claiming, unreasonably, that all the herbals of the period were "pirated" in one form or another. Though modern discourses of scholarly authorship regularly seek to credit specific figures with idiosyncratic discovery or inventive composition, sixteenthand seventeenth-century authors of herbals produced their works not sui generis but largely by incorporating and building upon the printed works of botanical scholarship that already existed. ${ }^{39}$ As Egenolff noted of Fuchs, Renaissance herbalists composed their texts primarily by "gathering," synthesizing, and commenting upon the materials of their predecessors and using this information as a scaffold upon which they could then record their own differing or dissenting experience. Frances E. Dolan links this kind of "compost/composition" with flourishing Renaissance cultures of recycling, while Jeffrey Todd Knight locates a "culture of compiling" that appreciated books' material status as "thing $[s]$ to actively shape, expand, and resituate as one desired." ${ }^{40}$ Brian W. Ogilvie characterizes this period of natural history as necessarily bibliographic, pointing out

37 See R. A. Foakes, ed., Henslowe's Diary, 2nd ed. (Cambridge: Cambridge University Press, 2002). As a representative example of Dekker's role in attribution scholarship, see D. J. Lake, "Three Seventeenth-Century Revisions: Thomas of Woodstock, The Jew of Malta, and Faustus B," Notes and Queries 30 (1983): I33-I43.

$3^{8}$ See John Twyning, "Dekker, Thomas (c. I572-I632), playwright and pamphleteer." ODNB, accessed June IO, 2019.

39 This problem is receiving increasing attention. In 2004, a trio of essays appeared in the journal Isis to surmise what the history of reading can offer to the history of science. See Blair, "Early Modernist's Perspective"; Jonathan R. Topham, "A View from the Industrial Age," Isis 95: 43I-442; and Daston, "Taking Note(s)."

$4^{\circ}$ Frances E. Dolan, "Compost/Composition," in Hillary Eklund (ed.), Ground-Work: English Renaissance Literature and Soil Science (Pittsburgh: Duquesne University Press, 20I5), 2I-39. 
that published texts were not the end product of the process of natural history research; rather, they were themselves employed as tools by naturalists seeking to make sense of their particular experience... Their technology of observation shaped habits of observation, and was in turn shaped by those habits, in a continuing dialectic that focused attention above all on defining and describing new species or varieties of plant. ${ }^{4 \mathrm{I}}$

Historians of botany who valorize invention and discovery have frequently struggled to account for this imitative and materialist method of composition and have often identified an author or publisher's replication of a previous herbal text as suspect, repeating and endorsing the claims that herbal authors themselves made to distinguish their works in a competitive print marketplace. These misgivings have even led historians to label some herbals as mere "piracies" of earlier volumes or some authors meager "plagiarists" of another's work. Scholarly narratives about reprints of the early Herball first published in 1525 thus characterize figures like Robert Wyer as a pirate of other stationers' books, while John Gerard is reviled for being a plagiarist owing to his use of a now-lost manuscript by one "Dr. Priest."

Attention to the context of the Tudor trade in vernacular books demonstrates that many of the seemingly illegitimate textual behaviors that have been ascribed to herbal publishers are instead normal stationer practice, while claims of "plagiarism" were often rhetorical ploys that served the interests of subsequent herbal authors leveling charges against their predecessors' scholarly credibility. The rest of this chapter attends to what is at stake in modern scholars' ratification of past claims of textual impropriety by explaining why it is crucial to distinguish between the agents who are responsible for the texts of verbal works (authors) and those who are responsible for producing copies of printed documents for sale (publishers and printers). While the financial and intellectual benefits to all of these figures frequently overlap, especially when an edition sells well, the particular motivations that lie behind authors' and publishers' investments in a text frequently differ, and it is instructive to separate the two roles. For example, while a herbalist's reputation as a man of letters might suffer after attacks from a competitor in print, a publisher will benefit from an intellectual controversy so long as their books continue to sell. Conversely, because the print publication of a book will establish the

Jeffrey Todd Knight, Bound to Read: Compilations, Collections, and the Making of Renaissance Literature (Philadelphia: University of Pennsylvania Press, 20I3), 4. See also Leah Knight, Of Books and Botany.

${ }^{4 \mathrm{I}}$ Ogilvie, Science of Describing, 207. 
priority of a discovery or idea, a natural historian can benefit socially regardless of an edition's success in the marketplace. Printed books enabled naturalists to gain a larger public, making their private labors known to a wide audience. As Ogilvie remarks, "while manuscripts preserved experience for their authors, published [i.e. printed] natural histories reproduced it for others." 42

Furthermore, the standards of intellectual propriety and legal ownership changed drastically over the course of the sixteenth century, shifting the norms of behavior for both authors and publishers. Chapter 2 therefore offers a history of the important changes in the way the Stationers' Company of London, the civic organization governing English printers and publishers, sought to regulate the production of books. When the Stationers' Company received a royal grant of incorporation in 1557, the Company's new means of authorizing printed texts began to place a latent value on unpublished works, which could theoretically underpin any number of future editions. While earlier systems of English patents such as the one held by Richard Bankes in 1525 allowed a patent-holding publisher to declare a particular text off-limits for a fixed period of time (usually seven years), the emergence of the Stationers' Company Registers permitted this kind of protected future speculation to become available to every London stationer who chose to register a title and to declare their ownership of those rights in perpetuity. Through the Stationers' new system of textual authorization, it therefore becomes possible to recognize precisely when piracy occurred, because a stationer could sue another for damages. Further, a textual work came to be recognized as a commodity in its own right - something that could be owned and something that therefore could be transferred - regardless of whether the would-be publisher ever actually had the work printed. By more thoroughly understanding the implementation and effects of the Stationers' system of title ownership, historians of herbals are in a better position to determine how both English booksellers and authors evaluated the dynamic market for printed books of natural history throughout the sixteenth and early seventeenth centuries.

42 Ogilvie, Science of Describing, I8I. Deborah Harkness argues that a "failure to publish proved fatal" to a sixteenth-century London community she titles the "Lime Street naturalists" who suffered anonymity as a result of the publication of John Gerard's Herball or General Historie of Plants of I597 (Jewel House, 55). 


\section{A Bibliographic Turn of the "Author-Function"}

As they were able to circulate through the channels of the early modern book trade both in England and on the continent, herbals were locations for plant investigators to publish theories that could later be confirmed or refuted by their fellows in their own publications. For example, in his A New Herball (London, I55I), Englishman William Turner refuted the Italian Pietro Andrea Mattioli's description of Orobanche or broomrape that the latter offered in his printed commentaries on Dioscorides' Materia medica. Mattioli had rebuked Dioscorides' milder account of the plant and asserted that broomrape was so chemically destructive that it could kill other plants living nearby without any physical contact. In A New Herball, Turner corrects Mattioli, suggesting that the Italian had not properly investigated his subject - if he had, Mattioli would have seen that in fact broomrape's roots strangle those of other plants. Agnes Arber sees Turner's clarification of his fellow herbalist as indicative of both his delight in "pouring scorn upon any superstitious notions which he detected in the writings of his contemporaries" and his respect in asserting the authority of ancient authors such as Theophrastus, whose commentary on broomrape Mattioli had summarily dismissed. ${ }^{43}$ To Brian Ogilvie, this kind of exchange is typical of "the dialectic between producing and consuming knowledge" that may be seen throughout Renaissance Europe as authors struggled to make and to communicate accurate observations of the natural world through the medium of the printed book. ${ }^{44}$

This dialectic reveals that the herbalists' dispute occurred neither in isolation nor in a restricted republic of letters between a handful of interested parties but publicly, in a marketplace filled with printed volumes of plant knowledge. The texts of Mattioli and Turner testify to the longcontested fight for scholarly authority over Europe's botanical landscape, with broomrape and other plants serving as individual battles in an enduring transcontinental war. Printed books were the field in which this battle for botanical description was fought, and the capital to produce these books was fronted not by herbalists but by booksellers eager to see their investments pay off. While the herbalists' attentions were, understandably, primarily focused on the content of their own authored works and the particulars of a plant, tree, or herb, the material fact of their works' sale as books in a public marketplace also concerned a group of figures who

\footnotetext{
43 Arber, Herbals, I24. ${ }^{44}$ Ogilvie, Science of Describing, 43.
} 
were attentive to the ways that such texts (and their authors) could be marketed to as many readers as possible.

Historians who focus on herbals primarily as transcriptions of botanical or medical data make an implicit distinction between books and the words that books contain in order to justify their focus on the intellectual and social history of a genre. By separating forensic history of material documents as the proper concern of bibliographers, such historians have good company - the distinction between words and books is one that is also frequently employed by literary and textual scholars as they edit and interpret written documents. Because verbal works are immaterial, originating from the mind of an author and ultimately recognized in the mind of a reader, because they can be translated between languages, and because they can be copied innumerable times and still be identified in terms of their linguistic similarities, works are often seen as divorceable from the medium in which they appear. There is, between the copies of the first quarto and first folio editions of Shakespeare's King Lear in 1608 and I623, enough similarity between the words of the two works to suggest that they are versions of the same thing, some idea of the play that has been rendered into a readable form with various degrees of perfection. ${ }^{45}$ In the same vein, the variations between Bankes's first edition of the little Herball in 1525 and Robert Wyer's first edition in or around I540 are negligible enough to view the texts of both books as versions of a single work, something that can then lead to a charge of "piracy" against Wyer for copying Bankes's printed text.

The question of what constitutes the essential components of a given work has been central to the occupation of textual scholars and editors for centuries, most of whom have been interested in uncovering an original, "intended" work of an author as it existed before it was rendered physically into the text of a manuscript or book. ${ }^{46}$ While recently textual theorists such as Jerome McGann have used sociological methodologies to defend critical editions of particular printed texts on the grounds that such enterprises better reveal the historical and social circumstances relating to the production and reception of copies of these particular documents,

${ }^{45}$ On the two texts of King Lear, see Gary Taylor and Michael Warren (eds.), The Division of the Kingdoms: Shakespeare's Two Versions of King Lear (Oxford: Clarendon Press, 1986).

${ }^{46}$ Two of the most prominent proponents of authorial intention as an editorial goal are Fredson Bowers and G. Thomas Tanselle, whose writings outline methodologies for its application and respond to criticism of its use. See Fredson Bowers, "Authorial Intention and Editorial Problems," Text 5 (1991): 49-62 and G. Thomas Tanselle, "Textual Instability and Editorial Idealism," Studies in Bibliography 49 (1996): I-60. 
scholarly interest in works, which are the products of authors, has not substantially waned. ${ }^{47}$ Along with the division of the text from its material form, central to many such literary studies of authorial intention is a curious, and often undisclosed, notion of property that insists that a text of a work belongs to its creator, an intellectual right that is distinct from the conventions of physical property governed by common law. ${ }^{48}$ Such a view holds that a book might be owned by anyone who purchases it, but regardless of how many copies of that book have been sold, the text of the book, or that material which represents the author's verbal work, is the intellectual property of the person who labored to compose it. ${ }^{49}$ Those who duplicate such texts without offering credit to the originating author are guilty of "plagiarism," the usurping of an author's authority over their own labor and a form of theft. ${ }^{50}$ In such interpretations, even as a text is unyoked from one documentary form to produce another document, the verbal work that underlies both documents is nonetheless bound firmly to its author. The copying of the texts of works to form the texts of new documents can lead to confusion, though, and a slippage that enables the words "work" and "text" to become synonyms sometimes occurs as a result of the two terms' similar relationship to their originating author. Scholarly focus on authorial works rather than physical documents elides the ways that the meaning of a text is shaped by a given medium.

Once it was examined in detail by poststructuralist critics such as Michel Foucault, whose 1969 essay "What Is an Author?" attempted to delineate the purpose of this "solid and fundamental unit of the author and the

47 See Jerome McGann, A Critique of Modern Textual Criticism (Charlottesville: University Press of Virginia, 1983). As Tanselle points out, a sociohistorical critical viewpoint and an editorial methodology that supports intentionality are not mutually exclusive: "an edition focusing on authorial intention, does not necessarily signify that the editor has failed to take the whole book, or the whole historical context, into account" ("Historicism and Critical Editing," Studies in Bibliography 39 (1986): I-46; 17). This essay also features a critique of McGann's Critique. See also Neville, 'Nibil biblicum.'

${ }^{48}$ On issues in copyright, see Mark Rose, Authors and Owners: The Invention of Copyright (Cambridge, MA: Harvard University Press, 1993).

49 "Labour gives a man a natural right of property in that which he produces: literary compositions are the effect of labour; authors have therefore a natural right of property in their works," William Enfield, Observations on Literary Property (London: 1774), quoted in Mark Rose, "The Author As Proprietor: Donaldson v. Becket and the Genealogy of Modern Authorship," Representations 23 (1988): 5I-85. Also quoted in Roger Chartier, The Order of Books: Readers, Authors and Libraries in Europe between the Fourteenth and Eighteenth Centuries, trans. Lydia G. Cochrane (Cambridge: Polity Press, 1994), Iooni4.

so "Plagiarism," $O E D$ : "The action or practice of plagiarizing; the wrongful appropriation or purloining, and publication as one's own, of the ideas, or the expression of the ideas (literary, artistic, musical, mechanical, etc.) of another" (I62I). On historical constructions of an author's work, see Chartier, Order of Books, chap. 2: "Figures of the Author." 
work," ${ }^{\text {II }}$ this covalent stance on authorship became, in Roger Chartier's terms, an "obligatory reference" for all scholars of the history of books. ${ }^{52}$ Foucault's demarcation of what he called the "author-function" served to establish that the idea of an authorial subject's production of an intended verbal work was, rather than an historical fact, merely a "discourse" constructed by later readers in order to unify and limit the boundaries of that work within a document. In Foucault's reading, an author's name became synonymous with cultural authority over a given subject matter or narrative by virtue of this author-function, which provides

more than an indication, a gesture, a finger pointed at someone ... it is the equivalent of a description ... an author's name is not simply an element in a discourse (capable of being either subject or object, of being replaced by a pronoun, and the like); it performs a certain role with regard to narrative discourse, assuring a classificatory function. Such a name permits one to group together a certain number of texts, define them, differentiate them from and contrast them to others ... it is a speech that must be received in a certain mode and that, in a given culture, must receive a certain status. ${ }^{53}$

Foucault continues his examination of the author-function to surmise that it does not affect all discourses or texts in a similar fashion, drawing a distinction between "literary" texts (which he explains includes "narratives, stories, epics, tragedies, comedies") and those texts "that we would now call scientific - those dealing with cosmology and the heavens, medicine and illnesses, natural sciences and geography." ${ }^{4}$ While the authors of literary works were long permitted their anonymity owing to "their ancientness, whether real or imagined, [which] was regarded as a sufficient guarantee to their status," "scientific" works were

accepted in the Middle Ages, and accepted as "true," only when marked with the name of their author. "Hippocrates said," "Pliny recounts," were not really formulas of an argument based on authority; they were the markers inserted in discourses that were supposed to be received as statements of demonstrated truth. 55

\footnotetext{
5I "What Is an Author?" was first delivered to the Société française de Philosophie in February 1969 and published as "Qu'est-ce qu'un auteur?" in Bulletin de la Société française de Philosophie later that same year. Josué V. Harari's translation quoted here in Early Modern Herbals and the Book Trade is of a revised version of the paper delivered at SUNY-Buffalo, and Harari discusses the variants between the two versions in Jousé V. Harari, Textual Strategies: Perspectives in Post-Structuralist Criticism (Ithaca, NY: Cornell University Press, I979), 43.

52 Chartier, Order of Books, 29. $\quad 53$ Foucault, "What Is an Author?," I05-IO7.

54 Foucault, "What Is an Author?," Io9. $\quad 55$ Foucault, "What Is an Author?," Io9.
} 
According to Foucault, the essential characteristics of these "literary" and "scientific" discourses reversed positions "in the seventeenth or eighteenth century," when "scientific" discourse no longer needed the influence of an author's proper name in order to be considered authoritative, bolstered instead by

the anonymity of an established or always redemonstrable truth; their membership in a systematic ensemble, and not the reference to the individual who produced them, stood as their guarantee. The author function faded away, and the inventor's name served only to christen a theorem, proposition, particular effect, property, body, group of elements, or pathological syndrome.

While "scientific" texts gradually gained authority through the methods of experiential and experimental science, which in turn anonymized their author-functions, Foucault argues, "literary" discourses began to depend upon the identification of the author as a pretext for the establishment of their authority.

Scholars of the Middle Ages have since challenged the accuracy of Foucault's historical account of literary and scientific authorship. ${ }^{56}$ However, I am less interested in the accuracy or generic particulars of Foucault's chronology of historical change than I am in the useful distinction he makes between an authorial subject and the role that an author's presumed assumption of status, or "authority," takes in a particular text or body of literature. Without this separation between authorship and authority, both textual scholars and historians may unwittingly collapse distinct forms of textual agency and fail to recognize the contingencies and constraints of the material artifacts that mediate our understanding of the past. It is the discourse of the author-function that textual scholars who support the constraints of authorial intention implicitly endorse in their methodologies, while it is likewise the discourse of the author-function that many historians of sixteenth- and seventeenth-century herbals employ in their analyses as they investigate the history of an "authoritative print herbal tradition." ${ }^{77}$ All too often in both kinds of scholarship, however, the role of the author as a discourse that can be constructed expost facto by later readers as a method of limiting and differentiating interpretations is overlooked. Foucault's assertion that the author-function is constrained

${ }^{56}$ Guillemette Bolens and Lukas Erne (eds.), Medieval and Early Modern Authorship (Tübingen: Narr Verlag, 20II); Alexandra Gillespie, Print Culture and the Medieval Author: Chaucer, Lydgate, and their Books I473-I557 (Oxford: Oxford University Press, 2006).

57 Laroche, Medical Authority, 5. 
by its context demands the establishment of that context for the unique circumstances of every would-be author: "it is a speech that must be received in a certain mode and that, in a given culture, must receive a certain status. $" 58$ The function in Foucault's author-function thus offers historians two crucial practical benefits in their discussions of the texts of written documents. First, the author-function presumes the existence of readers who will encounter the deployment of an authorial subjectivity and interpret such authorship in contingent and diverse ways. Secondly, by highlighting readers' role in the construction of meaning, the authorfunction implicitly calls attention to the materials and technologies of text that enable readers to construct their interpretations.

In their primary focus on the intellectual content, or works of herbals, scholars have sought to identify the provenance of specific ideas and concepts central to the development of modern botanical science, and in so doing, they have risked elevating the status of particular authors beyond the import garnered by authorship in given historical moments. This traditional logic proceeds as follows: the provenance of herbal works requires unraveling because as the texts of herbals were translated, copied, and distributed through the media of script and print, they were altered by figures other than their authors and potentially infused with meanings different from the ones originally intended. As herbal texts were transmitted through the physical vehicle of books, they could be separated from this accepted form of authority, rendering authored works anonymous or ascribed to authors who had nothing whatsoever to do with them. To remedy such confusion, many accounts of herbals have been preoccupied with locating the first author of a given classification scheme or method of plant description, considering it absolutely crucial to give authorial credit to the correct person in order to reassert the stability of the author-function. In such accounts it is the role of the historian to set acknowledgments to rights, to redeem the underappreciated author and condemn those "copyists" who shamefully and deliberately usurped the work of others. For example, Anna Pavord's popular history of plant taxonomy The Naming of Names is as much a history of plant classification schemes as it is a clarion call highlighting the decisive roles played by such early botanists as the Greek Theophrastus (37I to ca. 287 BCE), whose work was "shamelessly plagiarized and regurgitated" by Pliny the Elder in his Historia naturalis. 59 "Remember him," urges Pavord, who titles chapter 4 of her work "Pliny the Plagiarist." The same sentiments are also found in the works of mid-twentieth-century botanical historians, whose

58 Emphasis mine. 59 Pavord, Naming of Names, 24. 
attitudes still seem to influence more recent accounts. ${ }^{60}$ In a 1963 published lecture on "Herbals, their history and significance," George H. M. Lawrence repeats a similar refrain as Pavord. As he closes his speech with "the late British herbals of the seventeenth century," Lawrence maintains that "three are deserving of mention: one because it is so bad, the others for their excellence." "Th The one that is "so bad" is

John Gerard's The herbal; or general historie of plantes, published in London in I597. The iniquities associated with it, ably reviewed by Arber and others, are too many to be recited here. Suffice it to say that Gerard (I545-I6I2), an unscrupulous barber surgeon of London, purloined an unfinished English translation of the last edition of Dodoens' Pemptades of 1583 , bungled his part in the completion of the translation, laced it throughout with anecdotes, legends and fables - usually presented as facts - and published the whole as his own! Today's amateur herb lover may cherish the volume for its massiveness and antiquity and because its quaint English is readable. But the student of the history of science knows that almost every statement is suspect and that it is the production of a rogue. ${ }^{62}$

The botanical biographer Charles Raven is even more insistent on the issue: "Gerard was a rogue: of that there can be no doubt ... Gerard was a rogue. Moreover, botanically speaking he was, as has been indicated, a comparatively ignorant rogue."

As scientists writing from the context of twentieth- and twenty-firstcentury post-Enlightenment science, the botanists uncovering the history of botany are keen on distinguishing between fact and fiction and often work backwards from their own knowledge of plants derived from modern empiricism to evaluate the accuracy of the texts printed in early botanical books. Yet Renaissance naturalists weren't always governed by the same prescriptions for empiricist fact-finding as their modern counterparts, and such assumptions often misunderstand their earlier intentions. ${ }^{64}$

60 Brian W. Ogilvie, for example, twice refers to Gerard as a plagiarist. See Science of Describing, 37 , I88.

${ }^{6}$ I George H. M. Lawrence, History of Botany: Two Papers Presented at a Symposium held at the William Andrews Clark Memorial Library December 7, I963 (Los Angeles and Pittsburgh: The Clark Memorial Library and The Hunt Botanical Library, 1965).

${ }^{62}$ Lawrence, History of Botany, 17. A similar attitude towards medieval and early modern authors' "plagiarism" when they fail to properly cite sources can be found in the writings of botanical historian Jerry Stannard.

${ }^{63}$ Charles E. Raven, English Naturalists from Neckham to Ray: A Study of the Making of the Modern World (Cambridge: Cambridge University Press, 1947), 207-208.

${ }^{64}$ See Lorraine Daston and Katharine Park, Wonders and the Order of Nature, II50-I750 (New York: Zone Books, 200I). For the epistemological debates underpinning this topic, see Mary Poovey, A History of the Modern Fact: Problems of Knowledge in the Sciences of Wealth and Society (Chicago: University of Chicago Press, 1998). 
Nonetheless, scholars of the history of herbals consistently value the writings of those authors who claim that their works are written upon the basis of firsthand evidence, while those herbalists whose publications were derived not from their own experience but from book-learning are barely acknowledged as natural historians at all. Charles Raven's claim that Gerard, "botanically speaking ... was ... a comparatively ignorant rogue" is bolstered by the fact that Gerard's investigation into plants "seems to have been almost exclusively in the home counties," of which he then admits that Gerard "spoke with accuracy." "T5 Though he offers a paragraph celebrating Gerard's charm ("Rogue their author may have been: but when we have ceased to respect him as a botanist or esteem him as a man of honour we cannot fail to enjoy him"), Raven nonetheless refuses to consider the value that the publication of Gerard's Herball may have presented to the discipline beyond the narrow prescriptivism of the scientific method: "[b]ut we are concerned not with the charm of his writings but with their value as natural history; and beyond the defects already noted there are others." ${ }^{66}$ To scholars who privilege a form of authority derived from firsthand experience, the work of early herbal authors is degenerate unless it records and promulgates evidence of hands-on activity or originality. Thus, while Theophrastus' study of prior works, coupled with his own investigations, offered "a synthesis of the information about plants that was available at the time," and was "great and original," for Anna Pavord, Pliny's listing of more than Ioo sources for his Historia naturalis "added little new to the existing debate" and demonstrated only the names of those whose "work he plundered for his own." ${ }^{67}$ The possibility that, however unoriginal, Pliny's synthesis could provide a useful contemporary service in an age before print, where the survival of manuscripts was uncertain and rapid distribution of them impossible, is left unacknowledged. Because of his lack of originality in the content of his writing, Pliny's practical service to the field of botany is not only dismissed but condemned. For his use of the books of others, Pliny, the compiler of 37 books of Natural History, is a "plagiarist," while Gerard's I,400-page Herball or General History of Plants is the work of an "unscrupulous rogue" even as Gerard acknowledges his debts to Dodoens and L'Obel in his pages. Yet, as anthological gatherers, both Pliny and Gerard were well

\footnotetext{
${ }^{65}$ Raven, English Naturalists, 208, 20I. ${ }^{66}$ Raven, English Naturalists, 2I4, 215.

67 Pavord, Naming of Names, 25, I04, 64.
} 
within the norms of the different modes of textual transmission in which they labored to produce their work.

Such condemnations serve little purpose but to express either the contemporary moral outrage of historians on behalf of their various authorial subjects or their appreciation of what Adrian Johns calls "dramatic value." Without the recognition that the texts of works were created and distributed not as nebulous, free-floating ideas but as physical objects, books that were manufactured, sold, and circulated, scholars' righteous indignation does not fully appreciate the wider context in which botanical knowledge was made public in the early modern period. Before modern systems of copyright (or literary theory) yoked author and text together, such historical accounts of herbals accord with Adrian Johns in viewing all but the most modern forms of textual transmission to be illicit and immoral. ${ }^{68}$ The motivations for such illegality are naturally assumed to be economic, and as we saw with Fuchs's attacks on Egenolff, the economic motivations of a stationer are often understood to be at odds with the civic-minded nature of scientific truth. Further, cause and effect are often uncertain. It is unclear, for example, whether the popularity of the work with readers led to its frequent reprinting or if the reverse is true and the wider availability of a work in multiple editions led to its popularity with readers. Anna Pavord may argue that the publisher Peter Schoeffer's edition of a vernacular German herbal, Der Gart der Gesundheit (The Garden of Good Health, Mainz, I485), was popular because "a pirated edition" was immediately published by Johann Schoensperger in the same year, along with the "seven plagiarized editions in the next four years," but without investigating the book as a commodifiable object unto itself we are left with only a limited understanding of the role played by Der Gart der Gesundheit in its various "popular" forms. ${ }^{69}$ Because scholars have been preoccupied with herbals' authors, they have erroneously assumed that the correct ascription of authorship will solve the questions of authority that preoccupy many of these texts. In the early modern period, however, botanical authority is vested as much in the printed book form as it is in the verbal texts that authors composed.

\footnotetext{
68 John Feather, “The Book Trade in Politics: The Making of the Copyright Act of I7ıo," Publishing History 8 (1980): 19-44.

69 Pavord, Naming of Names, 160.
} 


\section{Considering the "Stationer-Function"}

Though Roger Chartier generally endorses Foucault's "What Is an Author?" as an invitation "to a retrospective investigation that gives the history of the conditions of the production, dissemination, and appropriation of texts particular pertinence," he nonetheless finds fault with Foucault's simplistic characterization of the "radical reversal" in the role of the author-function "between the seventeenth or eighteenth centuries." ${ }^{\prime \circ}$ Citing Steven Shapin, Chartier finds Foucault's depiction of scientific discourse without an identifiable author-function as authoritative to be inaccurate in the face of historical record. Chartier notes that, particularly in the case of experimental science,

the validation of an experience or the accreditation of a proposition presupposed the guarantee provided by a proper name - the proper names of those who, by their position in society, had the power to proclaim the truth. The fact that scholars and practitioners disappeared behind aristocratic authority in no way resulted in the anonymity of a discourse whose authenticity was not exclusively dependent on its compatibility with an already constituted body of knowledge. During the seventeenth and the eighteenth centuries a number of scientific texts displayed a characteristic that Foucault (perhaps wrongly) reserved to medieval works alone: later scientific texts were also "accepted ... and accepted as 'true,' only when marked with the name of their author" - an "author", however, who was long understood as someone whose social position could lend "authority" to intellectual discourse. ${ }^{7 \mathrm{I}}$

This is the point that Adrian Johns expands upon in his examination of how England's Royal Society came to be viewed as an authoritative locus for natural philosophy through its attention to publication. Chartier's and Johns's research suggests that the responsibility for a given discourse or text often rests in more than one person, indicating that the cognates "authorship" and "authority" are not always equivalent.

Often the locus of a work's creation is as much a publisher as it is a writer, calling into question which responsibilities should be allowed to define the author-function and demonstrating a need to keep the terms "work" and "document" distinct. Roger Chartier makes a similar point in his Order of Books, examining definitions of the word auteur in seventeenth-century French-language dictionaries to reveal that the word was not originally invested with the writerly connotation that modern

70 Chartier, Order of Books, 32. Chartier's translator uses the term "radical reversal" in reference to Foucault's depiction of the shift in literary-scientific authorial discourses on pages $3 \mathrm{I}$ and 58 .

${ }^{71}$ Chartier, Order of Books, 58-59. 
scholarship often takes for granted but has something closer to the English meaning of "agent." César-Pierre Richelet's Dictionnaire françois (I680) defines auteur as "the first who has invented something, who has said something, who is cause of something that has been done"; while Antoine Furetière's Dictionnaire universel (I690) likewise validates a number of practical and technical meanings, including "said also of those who are the cause of something" and "said in particular of those who are the first Inventors of something." ${ }^{72}$ Within such vagaries of import, the two definitions that Chartier views as precursors to auteur's later literary meaning, "he who has composed some printed book" (Furetière) and "those who have brought some book into the light" (Richelet), may be viewed as denotations of what we now understand as the printer or publisher of the book.

Though Chartier's intent with this chapter in Order of Books is not to link the terms bookseller and writer under the rubric of author- or auteur-ship but rather to contextualize Foucault's author-function within the pre-print eras, Chartier's efforts nonetheless manage to highlight the authoritative status accorded to all those producers of the book who can be said to be responsible for "bringing it into the light." Examining the systems of order employed by sixteenth-century French book catalogues, Chartier finds that "the authorfunction had no trouble harmonizing with the dependency instituted by patronage" and that "the patronage connection and the affirmation of the author together define the regime of assignation of texts." ${ }^{73} \mathrm{He}$ cites La Croix du Maine's Grande bibliothèque françoise as a case in point, a catalogue of "the works or writings of every author," which listed for all works "by whom they were printed, in what format or size, in what years, how many sheets they contain, and especially the names of the men or women to whom they were dedicated, without omitting all their entire qualities." 74 The above emphasis is Chartier's, whose main interest in this passage is addressing the subject of patronage, but the part of La Croix du Maine's quotation that Chartier does not emphasize is as relevant in locating historical conceptions of authority or responsibility, which apply not only to the agent who serves as a text's prime origin but also to those agents facilitating its distribution to a reading public, that is, publishers.

Such a broadening of the author-function to include multiple agents also opens up the venue for censorship and punishment that Foucault supplies in "What Is an Author?" In explaining the potential advantage of

72 Chartier, Order of Books, 40.

74 Chartier, Order of Books, 43.

73 Chartier, Order of Books, 43 
such a discourse, Foucault suggests that the author-function became necessary to provide a hierarchy that could adjudicate the responsibilities for textual production: " $t$ ] exts, books and discourses really began to have authors ... to the extent that authors became subject to punishment, that is, to the extent that discourses could be transgressive." 75 In his support of Foucault on this point, Chartier underplays the role of book producers and distributors in his efforts to locate the historical importance of "the" singular author, but his evidence nonetheless demonstrates just how transgressive and subversive the producers and distributors of books were understood to be in sixteenth-century France. The edict of Châteaubriant of June 27, I55I, affirms that "the author-function was thus constituted as an essential weapon in the diffusion of texts suspected of heterodoxy," but what Chartier's emphasis again demonstrates is a curious exclusion of other evidence that heralds the multiplicity of the author-function's subjectivity, for the edict also restrains printers:

It is forbidden to all printers to perform the exercise and status of impression except in good cities and orderly establishments accustomed to do this, not in secret places. And it must be under a master printer whose name, domicile and mark are put in the books thus printed by them [with] the time of the said impression and the name of the author. The which master printer will answer to faults and errors that either by him or under his name and by his order will have been made and committed. ${ }^{76}$

In the hierarchy of multiple responsibility, the Châteaubriant edict holds the master printer as primarily liable for the profusion of unorthodox texts, a fact that Chartier's later anecdotal evidence of convictions under the edict supports enough to lead him to assert that "it was printing that extended, hence that made more dangerous, the circulation of texts that defied authority." 77

The Châteaubriant edict of I55I finds a contemporary analogue in England, where a proclamation of Edward VI dated July 8, I546, includes a similar decree:

that from henceforth no printer do print any manner of English book, ballad, or play, but he put in his name to the same, with the name of the author and the day of the print, and shall present the first copy to the mayor

75 Foucault, "What Is an Author?", I08. On the effects of censorship on writers, and the possibilities for overcoming it by means of "purposeful ambiguity," see Annabel Patterson, Censorship and Interpretation: The Conditions of Writing and Reading in Early Modern England (Madison: University of Wisconsin Press, 1984).

${ }^{76}$ Chartier, Order of Books, 50, emphasis in the text. $\quad{ }^{77}$ Chartier, Order of Books, $5 \mathrm{I}$. 
of the town where he dwelleth, and not to suffer any of the copies to go out of his hands within two days next following. ${ }^{78}$

Later proclamations and statutes of both Edward VI and Mary I emphasize that the "penal appropriation" Foucault sees at play in the author-function was also located within the producers of books (here defined not just as printers but also as booksellers) and "players of interludes" - in other words, all those with the power to broadcast seditious material:

Be it enacted ... That if any p[er]son or p[er]sons after the xxth day of February next ensuing ... maliciouslie devise write printe or set forthe any maner of Booke Rime Ballade Letter or Writing, conteining any false Matter Clause or Sentence of Sclander Reproche and Dishonor of the King and Quenes Majesties or either of them ... or whosoever shall maliciouslie procure any suche Booke Rime Ballade Letter or Writing to bee written printed or set forthe ... that then and in every such cace the Offender and Offenders therein ... shall for his or their first Offence ... have his and their right hande stricken of. (January 1555$)^{79}$

The English state's need to control the distribution of unorthodox and treasonable viewpoints ultimately led to the crown's seeking assistance from the civic body best able to monitor the movements of one particularly effective broadcasting medium: print. Though in his biography of the Company Cyprian Blagden downplays the importance of Mary Tudor's granting of the privy seal to the Stationers' Company's charter of incorporation on May 4, I557, the act clearly marked the state's official recognition that the technology of the handpress posed a threat considerably more significant in scale than that proposed by the circulation of manuscripts or the singing of ballads. ${ }^{80}$ Unlike a synchronous sermon, printed pamphlets and treatises could be manufactured in the hundreds and thousands and, once produced, were available to be read, reread, and passed on. ${ }^{8 \mathrm{I}}$

78 Paul L. Hughes and James F. Larkin, eds., Tudor Royal Proclamations, 3 vols. (New Haven, CT: Yale University Press, 1964-I969), 272.

79 Thomas E. Tomlins and John Raithby, eds., The Statutes at Large, of England and of Great Britain: From Magna Carta to the Union of the Kingdoms of Great Britain and Ireland, 20 vols (London: G. Eyre and A. Strahan, I8II), 4:240-24I. This statute was used by Elizabeth I in 1579 to punish both John Stubbes, author of the anti-Anjou pamphlet The Discovery of a Gaping Gulf(STC 23400), and the work's publisher, William Page. Printer Hugh Singleton was also convicted, but his sentence was rescinded out of compassion for his advanced age. Both Stubbes and Page had their right hands severed and were imprisoned. Despite the risks, however, many printed editions failed to adhere to this edict.

80 Cyprian Blagden, The Stationers' Company: A History I403-1959 (London: George Allen \& Unwin, 1960), 19-20.

${ }^{81}$ Blagden, Stationers' Company, 29. 
Foucault's identification of the "penal appropriation" of the authorfunction is confirmed through historical research - indeed, this discourse did allow legal systems such as the English crown to control dialogue by the means of discipline - but it also serves a secondary function relevant in contemporary scholarship of the development of natural history. While it offers a vehicle for state censorship over the original production of discourses, the author-function simultaneously allows scholarly systems of accreditation and historical account to offer a form of censorship over the reception of discourse, as they license certain types of writing acts (such as accounts of personal experience) and condemn others (such as copying). A preoccupation with the writer in the author-function has led scholars of early printed books to disregard the multiplicity of the authorial subject (which includes booksellers and producers along with writers and government censors) in favor of a narrative that supposes, first, that texts are produced in a vacuum outside of the material realities of the printed book and, secondly, that the material book's productive agents are necessarily in competition with authors for the benefits resulting from the commodification of the text in question. Implicit in such a narrative is the belief that printers, publishers, booksellers, distributors, and anyone else involved in the book trade are parasites feeding on their writerly hosts. It is understandable that authors like Leonhart Fuchs traded in such narratives, but there is much less justification for scholars taking authors' biased accounts at face value.

The case of early modern herbals suggests that texts lacking an author are not necessarily without the advantages that Foucault ascribes to the authorfunction, which indicates that the relationship between authorship and authority is less causal than correlative and may be replaced by the characteristics of a particular artifact. Eleanor F. Shevlin finds that a paratextual element common to medieval texts, the incipit, serves a classificatory purpose in much the same way as Foucault's authorfunction, but it manages to do so while respecting the multiple agencies of both the artifact's form and its content. Shevlin suggests that the incipit was seen as an "informal" address, behaving "like conversational markers that featured authors introducing readers to their subject matter," highlighting the dialogic relationship between not only reader and author but also reader and publisher, the auteur responsible for "bringing the book into the light." ${ }^{2}$ Through Shevlin's model of titles as contracts, texts are

${ }^{82}$ Eleanor F. Shevlin, "To Reconcile Book and Title, and Make 'Em Kin to One Another: The Evolution of the Title's Contractual Functions," Book History 2 (1999): 42-77; 46, 47. 
united not with their authors but with their material vehicles and therefore may be seen as the product of the multiple agencies responsible for a document's physical creation. Given this helpful intervention, the term "text" may be defined as any artifact that expresses a meaning, one that is subject to interpretation by various human agents. ${ }^{83}$

Shevlin's influence might be seen in this volume's Introduction, which opened with an analysis of the word "herbal" and suggested that a book's title signified a publisher's approach to their production. Shevlin writes that a title

participates in the world outside the text. Situated on the border of the text, the title commands a far larger audience than the actual work that it labels a location that presents vast opportunities for its participation in cultural arenas. By casting such a wide contractual net, titles embody the potential to illuminate not just individual works, but reading processes, authorial composition, publishing practices, marketing trends, and generic transformations as well. ${ }^{84}$

Agnes Arber's I9I2 work Herbals, Their Origin and Evolution: A Chapter in the History of Botany $1470-1670$ is still considered one of the most influential texts on the subject and can be found cited in nearly every article and book on herbals that has since followed. Yet despite her focus not on the bibliographic elements of herbals but on their botanical content, Arber is unable to ignore the materiality of the book. Just as the publisher Robert Redman's renaming of Richard Bankes's 1525 Here begynneth a newe mater as a "boke of the properties of herbes" serves to illustrate the concerns of a book producer, so Arber's title demonstrates that herbals are objects operating in physical space through the notion of the book as a metaphor for understanding the botanical discipline. Herbals, those books "containing the names and descriptions of herbs, or of plants in general, with their properties and virtues," are to be understood as being but a "chapter" in a larger "history."

The appearance of such a metaphor is not altogether surprising. In the same manner that "herbal" is at once both a signifying noun for a specific type of book and an adjective describing that book's content, so is the word "history" heavily linked to its physical manifestation as written text. The second and third definitions of "history" in the OED emphasize the primacy of its written form, both citing as primary examples prefaces by

\footnotetext{
${ }^{83}$ My thinking here is indebted to D. F. McKenzie, "The Sociology of a Text: Oral Culture, Literacy, and Print in Early New Zealand", in Bibliography and the Sociology of Texts, 79-130.

${ }^{84}$ Shevlin, "To Reconcile Book and Title," 43-44.
} 
England's first printer, William Caxton. ${ }^{85}$ In his 1485 translation of Paris and Vienne, Caxton tells his readers that he has "undertaken to draw the history for you," an outlay spanning an intellectual effort not only in his translation from French to English but also in his literal construction of the printed pages that readers hold in their hands. Like Fuchs in his dedicatory epistle calling attention to the physical features of the printed book that materialize his status as an author, Caxton, as a printer, recognizes that intellectual and material responsibilities intersect in the artifact of a printed book. In "histories" as well as in "herbals," the physical book is never absent, a fact that herbalists themselves recognized as they composed the texts of their herbals by integrating information from the printed herbals that had been published earlier. While such activities have sometimes been understood as "plagiarism," such a description misses the point of the exercise: the work of herbalists was deliberately meant to be accretive and anthological rather than being entirely new and entirely original. In doing so, herbalists worked with the printers and booksellers who stood to profit from their sale and who pushed herbal authors to present their work in recognizable - and saleable - ways. In serving their "stationer-function," these agents of the book trade had the most to gain - and the most to lose from the printing of a herbal. The history of printed English herbals necessarily requires recognizing them as commercial artifacts, and such an inquiry might start with the Stationers' Company of London, the dominant organization that structured the ways in which English books were produced, distributed, and sold.

85 From the $O E D$ : “2. Spec. A written narrative constituting a continuous methodical record, in order of time, of important or public events. Those connected with a particular country, people, individual, etc."; "3. (Without $a$. or pl.) That branch of knowledge which deals with past events, as recorded in writings or otherwise ascertained; the formal record of the past, esp. of human affairs or actions; the study of the promotion and growth of communities and nations." 